\title{
BACKPULSE AND FILTER FEED VELOCITY EFFECTS ON NORTON FILTER PERFORMANCE (U)
}

\author{
by J. L. Siler \\ Westinghouse Savannah River Company \\ Savannah River Site \\ Aiken, South Carolina 29808 \\ Other Authors:
}

This paper was prepared in connection with work done under Contract No. DE-AC09-89SR18035 with the U. S. Department of Energy. By acceptance of this paper, the publisher and/or recipient acknowledges the U. S. Government's right to retain a nonexclusive, royalty-free license in and to any copyright covering this paper, along with the right to reproduce and to authorize others to reproduce all or part of the copyrighted paper. 


\section{DISCLAIMER}

This report was prepared as an account of work sponsored by an agency of the United States Government. Neither the United States Government nor any agency thereof, nor any of their employees, makes any warranty, express or implied, or assumes any legal liability or responsibility for the accuracy, completeness, or usefulness of any information, apparatus, product, or process disclosed, or represents that its use would not infringe privately owned rights. Reference herein to any specific commercial product, process, or service by trade name, trademark, manufacturer, or otherwise does not necessarily constitute or imply its endorsement, recommendation, or favoring by the United States Government or any agency thereof. The views and opinions of authors expressed herein do not necessarily state or reflect those of the United States Government or any agency thereof.

This report has been reproduced directly from the best available copy.

Available to DOE and DOE contractors from the Office of Scientific and Technical Information, P.O. Box 62, Oak Ridge, TN 37831; prices available from (615) 576-8401, FTS 626-8401.

Available to the public from the National Technical Information Service, U.S. Department of Commerce, 5285 Port Royal Rd., Springfield, VA 22161. 
WESTINGHOUSE SAVANNAH RIVER COMPANY SAVANNAH RIVER LABORATORY
WSRC-RP $-90-522$

Keywords: ETF, Norton Filters, Backpulse, Filter Feed Velocity

Retention time: Permanent May 8, 1990

TO: D. L. EISH

FROM: J. L. SILER

\section{Backpulse and Eilter Feed Velecity Effects on} Norton Eilter Performance

\section{SUMMARY}

A series of tests have been conducted at TNX using the $2.2 \mathrm{ft}^{2}$ Norton filter to solve the fouling problems observed with the ETF Norton system. The objective of these tests was to determine filter efficiency as a function of backpulse strength and feed velocity.

Based on experimental results, I recommend that the filters should be operated at the following conditions:

1. Backpulse Transmembrane Pressure/Eeed Transmembrane Pressure $(\mathrm{BP} / \mathrm{FP})>1.5$, preferably 2 or 3.

2. Eeed crossflow velocity $=6-8 \mathrm{f} / \mathrm{s}$.

It is expected that operation at these conditions should improve performance by $30-60 \%$.

\section{DISCUSSION}

Effect of Feed Crossfilow Velocity - The results from these tests indicate that operating at a feed velocity of $6-8 \mathrm{f} / \mathrm{s}$ improved the filter performance over operation at 10-12 f/s (present Plant conditions). Figure 1 shows that the flux loss after 20 hours of operation increased from $45 \%$ to $65 \%$ for feed velocities of $6 \mathrm{f} / \mathrm{s}$ to $12 \mathrm{f} / \mathrm{s}$, respectively. This is probably due to the formation of a more effective dynamic filter layer at $6 \mathrm{f} / \mathrm{s}$, resulting in less particulate penetration into the filter. The results obtained at 
6 and $8 \mathrm{f} / \mathrm{s}$ were nearly identical. The ETF could utilize these results by using smaller feed pumps.

Effect of Backpulse Efficiency - Figure 2 shows filter flux data for three different backpulsing conditions:

\section{$B P / E P$ RATIO}

1.5

1.5 , then 3 3

\section{BACKRULSE_DUR. /FREQ.}

3 seconds $/ 3$ minutes

3 seconds $/ 2$ hours, then 3 seconds $/ 3$ minutes 3 seconds/3 minutes

Figure 2 indicates that present plant conditions do not allow for efficient backpulsing, which is crucial to filter operation and life. Altering the backpulsing conditions from BP/FP $=1.5$ to 3 restored a substantial amount of lost capacity and, more importantly, resulted in the same flux behavior at 20 hours as occurred from starting the test at $B P / F P=3$. Operating at $\mathrm{BP} / \mathrm{FP}=1.5$ with backpulsing set at three minutes appeared to give slightly better performance (in terms of flux restoration) than with backpulsing set at two hours.

There are several methods to boost the pressure ratio. The easiest method is to install an orifice plate in the filter feed line. This would reduce the feed pressure. The negative aspect is that lower feed pressure could limit filter productivity as the filters become fouled (i.e., lower maximum pressure = lower maximum flux). A second, more costly alternative is to increase backpulsing pressure, which could possibly require extensive system modifications.

It should be stressed that these results were obtained using simulants, and that various feed solutions could give different results. The results are intended to be viewed on a relative basis.

JLS : bcs

cc: W. L. Tamosaitis, 773-A

S. Wach, 703-H

K. Sullivan, 703-H

D. Brown, 703-H

A. Wiggins, 703-H/ETF

D. McCabe, 676-T

M. Poirier, 676-T

L. Kilpatrick, 676-T

SRL Records, 773-A 


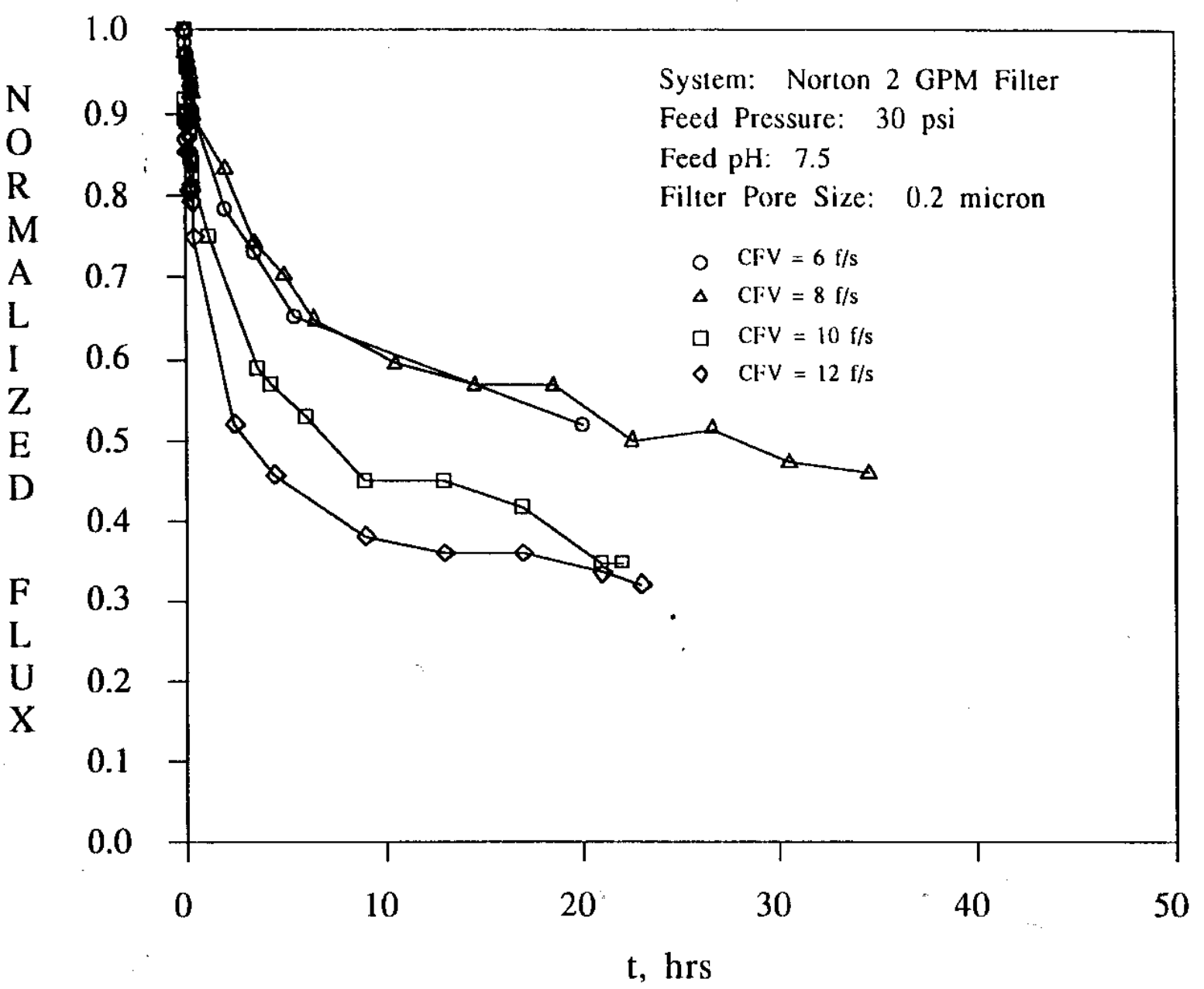

0
0
0
0
0
0
0 


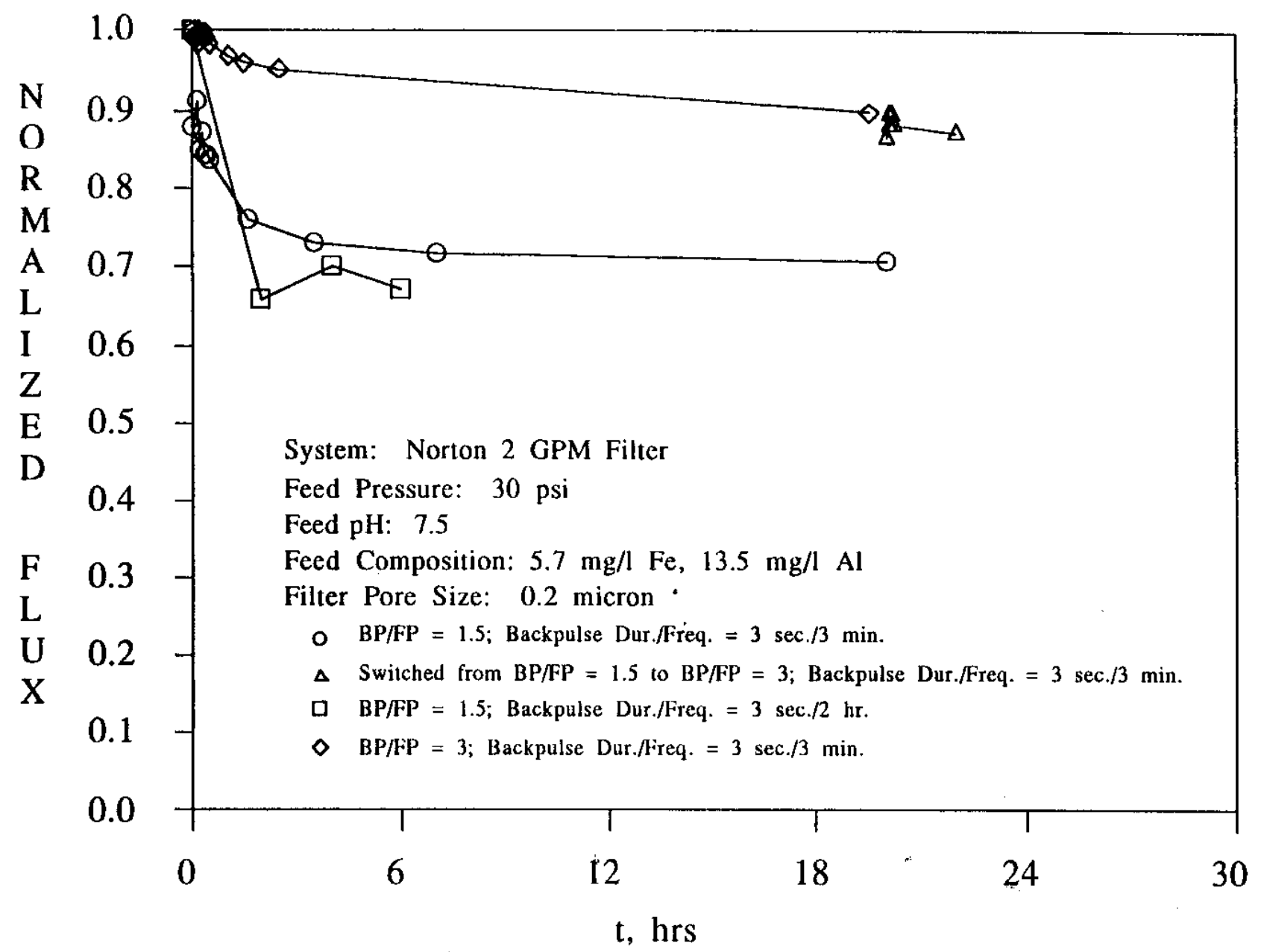

Figure 2 - Filterability as a Function of the Backpulse to Feed Pressure Ratio. 